\title{
The role of the audit in the prevention and detection of corruption events: Evidence of the 2016 Rio Olympic Games
}

\author{
Lorena Furtado(iD), Tatiane Antonovz(iD), Blenio Peixe(iD), Michael Correa $(\mathbb{D}$ \\ Universidade Federal do Parana (Brazil) \\ lorenlucena@gmail.com,tatiane152@hotmail.com,bleniocsp@gmail.com,micdias@hotmail.com
}

Received March, 2018

Accepted April, 2020

\section{Abstract}

Purpose: This research aimed to analyze the Public Choice Theory, from the opportunism point of view, and the actions related to evidence of corruption practices. As a focus of investigated policy, the study was focused on the Rio 2016 Olympic Games held in Brazil and the services hiring procedures.

Design/methodology: This was a qualitative and quantitative research, looking for official data and media information. The analyzed data were the audit reports issued by the Comptroller General of Brazil (CGU) and the news published by The Guardian and Le Monde, both from 2009 to 2016.

Findings: Regarding the audit reports, from 41 units, 17 presented inconsistencies about the bidding process or execution after such procedure, and in some cases concomitantly, that indicates corruption practices. Changing to the news, 34 from a sample of 38 units were analyzed.

Research limitations/implications: The research focuses on 2009 to 2016, but even with this limitation, it shows the main period that the news and investigations happened regarded to the Olympics in Rio.

Practical implications: The results show that, according to the Public Choice Theory, the public agents tend to make decisions that bring benefits only for themselves, not to the public in general. It is worse when talking about a global event, like the Olympics, when all the eyes from the world are in only one specific place.

Social implications: These documents presented actions related to bribes, illegalities in bidding processes and investigations related to politics in Brazil, corroborating the Public Choice Theory regarding opportunistic practices of managers in the primacy for one policy over others. Even with some politicians and public managers arrested at first, it didn't last long. After some months, most of them were free or under probation.

Originality/value: As the main contribution, this research shows the results of a set of media news and official reports investigating the expenditures for hiring some key services for the Olympics that happened in Rio 2016. Fraud and corruption evidences were found in most of the cases analyzed between 2009 and 2016.

Keywords: Audit in Prevention, Detection of evidences of corruption, Rio 2016 Olympic Games, corruption

Jel Codes: G18, G28, G38, H50, I18 


\section{To cite this article:}

Furtado, L., Antonovz, T., Peixe, B., \& Correa, M. (2020). The role of the audit in the prevention and detection of corruption events: Evidence of the 2016 Rio Olympic Games. Intangible Capital, 16(1), 14-30. https://doi.org/10.3926/ic.1360

\section{Introduction}

Corruption can be explained under different prisms and it is related to small values and favor exchanges or can cover the highest levels of a government. At this level, as (Monteduro, Hinna \& Moi, 2016)point out, corruption produces great exchanges of advantages and abuses of power, and eventually permeates the structures of society.

Nowadays, these deviations are drawing attention, since corruption is recognized as a way of deteriorating not only the institutions or a system, but the entire legal and social structure of a country (Monteduro et al., 2016; Olmos, Bellido \& Román-Aso, 2020; Pfleegor, Soebbing \& Seifried, 2019). Its presence can be associated not only with routine issues, but also with public policies aimed at meeting social demands and complying with the legal functions and obligations of the State.

These public policies are based on practices carried out by the managers of a government, in which the Public Choice Theory helps in the understanding of the incentives that each agent receives in its action in a given political system and the gaps arising from this relationship. James Buchanan and Gordon Tullock in their book "The Calculus of Consent: Logical Foundations of Constitutional Democracy" (Buchanan \& Tullock, 1962) emphasized this perspective.

It is observed that the exchange of advantages related to public managers form the gaps where the possibility for small and large corruptions arises, as in the case of the choice and organization of the Olympic Games throughout history (Dichter, 2016; Mason, Thibault \&Misener, 2006; Matheson, Schwab \& Koval, 2018).

Decker (2019) and Yavuz (2016) report that, specifically, the Olympic Games since its earliest days in 388 b.C. have records of bribery and other recognized illicit acts, pointing to a path that continues to the present day.

Nonetheless, Lima (2016) states that a democratic system based on reciprocal controls, free press and with internal and external control institutions, such as the Accounting Offices and the Brazilian Government Agency for Law Enforcement, can minimize the opportunities for corruption that arise due to these incentives.

With the same thought, the audit carried out by the Comptroller General of Brazil (CGU) has as its main scope to evaluate the execution of government programs, to verify their legality and to evaluate the results (Brasil, 2017b). The CGU also emphasizes the improvement of the management and the correct execution of public policies that help in the fight against corruption from different perspectives.

Some researches emphasized in corruption and deviation from the rules, in addition to the sanctions eventually obtained by fraudsters and the corruption perceived in each of the events, as it was the case not only at the Olympic Games, but also at World Cups (Matheson et al., 2018; Olmos et al., 2020; Pfleegor et al., 2019). However, from the point of view of investigations and performance of local government agencies, such researches did not have this focus, only analyzing the cases themselves.

This paper investigates the role of the CGU audit in preventing and detecting evidence of corruption in the 2016 Olympic Games in Rio de Janeiro. Therefore, this research aims at understanding the main findings presented in the CGU audit reports for 2014, 2015 and 2016 and how they help in understanding the mechanisms for preventing and detecting evidence of corruption at the 2016 Olympic Games. 
Therefore, when having the corruption perception from the Public Choice Theory, this research contributes to increase the understanding of a contractual relationship in which the government should act in favor of society and use the resources that are managed, neither in favor of their own interest nor in an opportunistic way. Thus, the Public Choice Theory assists in understanding how to minimize political opportunism, as well as possible behavior associated with corruption and illicit acts (Andreff, 2019; Banerjee, 2019). The research is justified not only for the empirical evidence documented by the CGU in its audit reports, but also for other official boards that presented demonstrations of illegality related to the 2016 Olympic Games in Rio de Janeiro.

The press also has a prominent role in this scenario, since it has widely publicized issues related to diversion, fraud, bribes and even the purchase of votes in the choice of Rio de Janeiro as the venue for the 2016 Olympics, which resulted in an operation of the Brazilian Federal Police called Unfair Play.

\section{Theoretical framework}

\subsection{Corruption}

Corruption is a concept that is difficult to define itself. However, there is a consensus among authors who agree that it's everywhere and, in one way or another, it's connected to the question of human behavior throughout history (Abdul, Yusoff \& Mohamed, 2019; Banerjee, 2019; Liu, Moldogaziev \& Mikesell, 2017). The authors state that one of the difficulties related to the definition of this topic is related to the dependence of a country's regulatory system, which may change the perception that corruption is from a legal point of view.

For Jain (2001), the issue then becomes a problem when there is an attempt to define the concept of corruption, determination of a specific model and how it can be measured. The author states that, despite the lack of a precise description, there is agreement that corruption is related to acts of public managers. This would be linked to personal gains that counter the rules of the game in a nation.

Corruption occurs in a society, in an elementary way, when a position of trust is used for private gain (RoseAckerman, 1997). Within the public sector, corruption is considered endemic and affects all countries, with varying degrees of intensity (Andreff, 2019).

Shleifer and Vishny (1993) show that corruption in government is characterized by the sale of public agents motivated by personal gain. Some examples given by the authors are accepted bribes in exchange for licenses, passage clearance at customs or a ban on competitors in the local market. These authors cite that corruption is common in developing countries and that it usually compromises part of the Gross Domestic Product (GDP).

Thus, corruption can be understood as damaging to the public interest in general (Monteduro et al., 2016). Corruption can also be considered persuasive and, in some cases, essential for obtaining goods and services. In these situations, someone pays an officer to assure certain property or something in return. In some African countries, for example, not even direct bribery can ensure that certain objectives are achieved. In these cases, other illicit maneuvers are necessary to obtain what is desired (Andreff, 2019; Clarke \& Ojo, 2017). However, there are no limits to the wrongdoing, and corruption can also plague democratic and developed nations (Matheson et al., 2018).

Jain (2001) divided corruption into three distinct types within democratic societies and related it to population and politics, to administrative issues and to the judicial elite. These three types of corruption differ among themselves and also in relation to the decisions that are influenced by them, by the source of power or the decision maker. It is at this moment that opportunism arises responsible for acts of corruption.

"Great corruption" or high-level corruption is linked to elite political acts that exploit power to create or change economic policies and rules. Jain (2001) argues that politicians should make decisions only in favor of their principals - the population - and for this they should evaluate their interests.

The second type of corruption, the bureaucratic one, is also known as the "little corruption". In these cases, Jain (2001) states that the population needs to pay to receive services or to make them faster, such as those linked to 
the judiciary of a country. Legislative corruption refers to the behavior of a legislator and how this can be influenced by a group of interests. This is the type of corruption known as vote buying.

Specifically, in the great corruption, a corrupt elite appears when there is a change of the national policies or there is the implementation of rules aiming the own interests instead of the society ones.

The great corruption, besides a certain difficulty in its identification, also has obstacles in its measurement, since some sectors of the economy of a country got benefits from the deviations that are generated by the crimes committed. This type of corruption usually also ends up involving the private sector, which is responsible for payments for various government advantages (Olmos et al., 2020). Jain (2001) points out that this corruption can be explained by models based on Agency Theory, where efficiency depends on the relationship between the agent and the principal and the ability of the agent to develop appropriate incentives for the agent.

The agent's behavior, who is the public manager, is restricted by the principal's ability to define precise rules and monitor this agent. The imprecision of the rules and the costs of monitoring the agent by the principal will determine the leeway he has for corruption(Jain, 2001).

For Anderson and Hill (1986), this view of government as a firm contracted by citizens presented in the Agency Theory and used by them to obtain their most basic rights, in addition to any existing gaps and costs of this relationship, was explored by Buchanan and Tullock (1962), presenting itself as an important contribution to the Public Choice Theory. This concept allows the understanding of how to minimize some aspects of this relationship that can lead to corruption and that will be explored later in this paper.

Also from this perspective, Article 9 of the United Nations Office on Drugs and Crimes (UNODC) adopted at the UNODC General Convention in 2003 is a legally binding instrument against corruption. It recognizes the dangers and impacts of corruption (UNODC, 2013).

In this collection of rules, this board criminalizes these acts by putting rules and measures to prevent, increase the force of international cooperation in the fight against corruption and ensure that the resources are returned to the countries in which they have been diverted.

These rules, with the Handbook of Good Practices to ensure compliance with Article 9 of the United Nations (UNODC, 2013), put forward mainly actions of practices aimed at curbing actual acts of corruption in biddings.

Rose-Ackerman (1997) points out several irregularities related to this process, emphasizing different gaps that can be observed by the principal opportunistically to obtain advantages that can be considered as corruption.

\subsection{Public choice theory and corruption}

In public choices there are elementary concepts to define the action of the people. Buchanan and Tullock (1962) state that the decision-maker is an agent designed to manage a particular need in the name of collective interest. Therefore, there is an individualist dimension that falls on the rationality of that decision-maker regarding opportunistic issues in his actions.

Thus, existing contracts between individuals with common interests should be highlighted to minimize agency problems. Such a problem arises from the contractual relationship of one or more persons (the principal) with another person (the agent), who will make decisions about a particular entity on his behalf.

The agency problem occurs when there is a conflict of interest between the agent, who will act on the goal of maximizing his or her particular welfare, and the principal, which should align their interests with those of the managers, causing agency costs (Jensen \& Meckling, 1976).

In the opportunist perspective, the Public Choice Theory has as its differential the fact of assisting in the management aspects, placing the agents of different institutions on an equal basis as everyone will act to maximize their interests, regardless of whether or not they are in the capital market (Kelman, 1987; Mbaku, 2008). 
Nevertheless, this theory has its distinction as it can be considered as a branch of the economy that analyzes how the state, for example, makes its decisions in the public management, that is, how the public agents make the decisions on taxes, expenses, forms of regulation and other policies of public interest (Adanali, 2017).

Understanding the behavior of managers means that society can establish mechanisms to mitigate opportunistic and altruistic behavior. Constitutional regulations represent one of the ways found for private choices to meet the choices that affect the welfare of the community. In this area, the Public Choice Theory brings an approach on constraints to avoid the opportunism of managers, in order to limit, for example, corruption (Banerjee, 2019; Liu et al., 2017).

There are limitations in verifying all clauses that could be within a contract, motivated among other circumstances by the costs of monitoring. In post-contractual opportunism, for example, it happens that the actions of agents who violate established norms are motivated by opportunistic behaviors derived from the agent-principal relationship within the public sector (Monteduro et al., 2016). Thus, in the existence of incomplete contracts, corrupt public agents tend to direct greater compensation to the contractor. Along these lines, Iossa and Martimort (2016) point out that corruption is a threat to risk management and the agentprincipal relationship (Buchanan \& Tullock, 1962).

Corruption can have a direct impact on economic development (Andvig, Fjeldstad, Amundsen, Sissener \& Søreide, 2001) and also on government policies.Seter, Theisen and Schilling (2018), in a research in Africa, emphasizes the corruption damages in limiting the participation of ethnic, social and racial groups, once a domain relationship is established in which the minority of political groups acts. Corrupt acts have repercussions on efforts to the poverty.

In general, the absence of restrictions on the managers' behavior who have the power to regulate or manage public resources leads to incentives in governments for the practice of bribery, resulting in corruption (Abdul et al., 2019; Banerjee, 2019; Liu et al., 2017).

\subsection{Corruption in the Olympic Games}

On the topic of sports-oriented choices, there is evidence of corruption, especially in the Olympic Games. They appear in literature from the earliest times with the first documented corruption case in international sports being attributed to the athlete Eupolos from Thessalia. The sportsman successfully bribed three of his competitors in a fight at the first Olympic Games in history, in 388 b.C. (Decker, 2019; Yavuz, 2016). It's also reported other scandals surrounding the Olympics through the years with different types of corruption.

The scandal at the Salt Lake City Olympic bid in 1988 contributed to a change in the organization of the International Olympic Committee. The intention was to mitigate acts that could interfere in the choices of the Olympic venues (Mason et al., 2006).

In the world scenario, the interest in conducting the Olympic Games can be explained by several factors. After the Los Angeles games in 1984, it was noted that such an event would bring advantages beyond social issues (Brittain, Bocarro, Byers \& Swart, 2017; Mason et al., 2006). Political issues also drive the choice of hosting such an event. As an example, the games in Seoul have contributed to the modernization of South Korea. Nevertheless, there is an Olympic legacy that theoretically stays for years within a country that has held this event. The latter makes entrepreneurs and politicians want to foster the event in the country to be linked to their particular legacy (Dichter, 2016; Lee, 2017).

Recently in Brazil evidences of corruption in the 2016 Olympic Games were observed, mainly, in the hiring for the execution of services like construction of infrastructure for the accomplishment of the event. This finding is showed in the audit reports carried out by the CGU to the Ministry of Sports.

The resources applied in the 2016 Olympics were intended to provide a legacy that would make available to society, in particular, equipped sports facilities and support for research into sports. As a result, the invested 
amounts were budgeted at around US\$ 1 billion (Brasil, 2017a). The guarantee in this context would be focused on the social welfare aiming at the quality of the individual and his citizenship (da Costa, 2008).

In this sense, there is a special attention to the investments associated with public choices aimed at sports actions, which is the behavior of managers in the interest of performing a certain action to the detriment of others and of eventual benefited by these acts (Buchanan \& Tullock, 1962; Mbaku, 2008).

Olmos et al. (2020) argue that corruption in sports occurs in a distinctive way, being used to achieve certain opinions, which influence the allocation of television rights or other types of rights, or related to construction and its contracts, representing a number of issues never imagined.

\section{Methodological procedures}

This research is classified as descriptive and qualitative. Barbosa da Silva, Godoi and Bandeira-de-Mello (2010) affirm that qualitative research does not seek regularities, but the understanding of agents and what led them to act. This paper is written through a documentary survey (secondary data) and content analysis.

In the documentary research, the available information of the audit work was compiled with the Ministry of Sports, responsible for the hiring and execution of actions related to the Olympic Games in Brazil.

The first phase was characterized as a previous organization of the analysis, a period characterized by intuitions, but that sought the systematization of ideas for the development of operations aimed at the data exploitation (Bardin, 2009).

In the content analysis, irregularities in hiring between the Ministry of Sports and hired entities were identified on the CGU reports. The audit reports and Annual Accounts Audit Reports are from 2014, 2015 and 2016.

A survey was also made based on the data analysis with press reports from 2009, with Rio de Janeiro being chosen the venue for the Olympic Games, until 2016 when the event happened.

Some evidences were presented during 2017, related to the special operations of the Brazilian Federal Police and other events related to the investigation of acts of corruption and deviance occurred at that time. Therefore, the steps of there search are in accordance with the precepts enunciated by (Bardin, 2009): (a) survey of inspection and audit reports related to the rendering of accounts on the CGU's website; (b) data analysis content; (c) identification of irregularities framed as suspected corruption; (d) survey and analysis of news with the international media.

The reports related to the 2016 Olympics and possible indications of corruption were analyzed based on the definition described in the literature (Rose-Ackerman, 1997; Shleifer \& Vishny, 1993) and Article 9 of the United Nations Office on Drugs and Crime (UNODC, 2013), presented below.

\begin{tabular}{|l|l|l|}
\hline Genre & Characteristics & Risk \\
\hline Open bidding process. & $\begin{array}{l}\text { Any company can participate. The process is } \\
\text { detailed and the winner should be the one } \\
\text { who offers the lowest price. }\end{array}$ & $\begin{array}{l}\text { Reduced risk of corruption by open } \\
\text { participation. This should be } \\
\text { encouraged. }\end{array}$ \\
\hline Restricted bidding process. & $\begin{array}{l}\text { In this type of process only pre-selected } \\
\text { companies can participate. It can occur when } \\
\text { an object is very specific. }\end{array}$ & $\begin{array}{l}\text { It can have the risk of mitigated } \\
\text { corruption if participants' credentials } \\
\text { are required. Reasons for using this } \\
\text { type of procedure should be in the law } \\
\text { and should be applied restrictively. }\end{array}$ \\
\hline Negociated bidding process. & Only in case of emergency. & $\begin{array}{l}\text { To mitigate the risk of corruption it } \\
\text { must be strictly defined in the law and } \\
\text { should only happen in extreme } \\
\text { situations. }\end{array}$ \\
\hline Single participant bidding process. & Only in case of emergency. & $\begin{array}{l}\text { Higher risk / Favoritism } \\
\text { It should be documented, justified and } \\
\text { only occur in extreme situations. }\end{array}$ \\
\hline
\end{tabular}




\begin{tabular}{|l|l|l|}
\hline Genre & Characteristics & Risk \\
\hline Publication of bidding conditions. & $\begin{array}{l}\text { All requirements for participation in the } \\
\text { bidding process must be detailed and } \\
\text { published. Details of the process should also } \\
\text { be published. }\end{array}$ & $\begin{array}{l}\text { Essential requirement for transparency } \\
\text { in the process. Advertising ensures } \\
\text { that the procedures applied are in } \\
\text { accordance with the law and allows the } \\
\text { prosecution in case of all steps have } \\
\text { not been followed. }\end{array}$ \\
\hline $\begin{array}{l}\text { Pre-determined objectives as a } \\
\text { criterion for participation in the } \\
\text { bid. }\end{array}$ & This process should preferably be electronic. & $\begin{array}{l}\text { To avoid evidence of corruption, the } \\
\text { criteria for participation in a bidding } \\
\text { process must be pre-determined. In } \\
\text { addition, no drastic changes to the } \\
\text { object should be made during the } \\
\text { process. }\end{array}$ \\
\hline $\begin{array}{l}\text { Responsibility of public managers } \\
\text { in the bidding process. }\end{array}$ & $\begin{array}{l}\text { Conflict of interest statements, screening } \\
\text { procedures and training. }\end{array}$ & $\begin{array}{l}\text { Corruption can be avoided in this } \\
\text { regard by promoting standards of } \\
\text { probity and integrity in all } \\
\text { interpersonal relationships. }\end{array}$ \\
\hline Budget. & $\begin{array}{l}\text { After the entire process there should happen } \\
\text { the indication of the use of resources. }\end{array}$ & $\begin{array}{l}\text { Evidence of corruption may be } \\
\text { related to very high costs and amonts } \\
\text { out of the market. The electronic } \\
\text { processcan help mitigate these } \\
\text { problems. }\end{array}$ \\
\hline
\end{tabular}

Table 1. Definition of evidence of corruption (UNODC, 2013)

In addition, a content analysis of possible deviations and illicit indications based on the Brazilian Auditing Standards was carried out. Also, the legislation applied to the public sector was identified, as is the Act 4,320/64 (Darós \& Pereira, 2009) and Act 8,666/93 (Brasil, 1993), Act 12,462/2011 (Brasil, 2011) and other standards laid down by the CGU.

The chosen media was the British newspaper The Guardian, the third largest in the world and relevant in the investigative area, winner of the 2014 Pulitzer Prize for journalism, highlighting its global vigilance. In the area of sports, it shows several relevant reports related to the International Olympic Committee (IOC), International Football Federation (FIFA) and other sports-related boards.

Complementary information was used in the French newspaper Le Monde, responsible for denouncing payments to the IOC before choosing Rio de Janeiro as an Olympic city. Such news was analyzed using the qualitative software Nvivo, version 10.

The qualitative data analysis in this point, as emphasized by Gibbs (2009), besides the manipulation and interpretation of the data, used the reduction of these data in abstracts made from the use of the chosen software for the analysis. For this process, the data coding under analysis was used.

In this research it was used the concept-based coding that, according to Gibbs, can come from: (i) the research literature, (ii) previous studies and (iii) and perceptions about what is happening, just as it was delimited in this paper.

Following the concepts of Gibbs (2009), were created concepts based on the observation of the actors based on acts and behaviors, events occurred, activities and practices observed, as well as consequences of these acts and the context observed around the news. Finally, the interpretative analyzes of all the explored material as well as the observed conclusions were made.

\section{Analysis of results}

This work initially analyzed the monitoring and auditing reports performed by the CGU, the board in charge for overseeing hiring between public entities and third parties, in conjunction with contracts signed between the Ministry of Sports and other private entities. Subsequently, the observations of the media components related to The Guardian newspaper were identified. 
Focusing first on the CGU reports, the intention to verify the inspections with the Ministry of Sports was motivated because it's responsible for carrying out various actions for the 2016 Olympic Games. Mainly related to Program 2035 - Sports and Major Events / Action 20D8 - Preparation and Organization of the Rio 2016 Olympic and Paralympic Games and Action 14TQ - Implementation of Infrastructure for the Rio 2016 Olympic and Paralympic Games.

The data refers to the years from 2010 to 2016, executed from 2014 to 2016. We found 48 audit reports, and 41 were related to contracts, partnership terms and agreements, 3 were related to the annual accountability and 4 were audit standards. In order to reach the research objective, the content analysis took place on the contracts, terms of partnership and agreements.

In order to filter these reports, the CGU's website that lists the audit reports made in states and municipalities, program evaluations, among others, included the parameters "Ministry of Sports" and "Publication Period" between 2009 and 2016. After downloading such reports, those specifically related to the execution of the Rio 2016 Olympic Games were considered for content analysis.

Firstly, we will highlight the evidences about the execution of public money made by those who signed partnerships through contracts, agreements and terms of partnership with actions 20D8 and 14TQ on the Rio 2016 Olympic and Paralympic Games.

From the 41 CGU audit reports found regarding partnerships between the Ministry of Education and hired entities, only one of them was excluded, since it was not related to the actions highlighted in this research, as follows:

\begin{tabular}{|l|l|r|}
\hline Type of agreement & Object & Quantity \\
\hline Contract & Services & 07 \\
\hline \multirow{3}{*}{ Agreement } & Goods & 06 \\
\cline { 2 - 3 } & Services & 20 \\
\cline { 2 - 3 } & Goodsandservices & 02 \\
\hline Term of Commitment & Goods & 05 \\
\hline Total & 40 \\
\hline
\end{tabular}

Table 2. Reports by type of agreement and objects

The 27 reports are derived from agreements for the provision of services. Included in such services are those to support mainly the preparation of teams of athletes for the Rio 2016 Games. The highlights are the hiring procedure to participate in the games, advisory services regarding the displacements of the athletes and their technical staff, consulting for the preparation of projects and analysis of facilities.

In some reports the compliance of the bidding process was identified. Regularities were also identified during the execution and rendering of services or delivery of the acquired goods. However, in other processes, consistency was indicated only in the execution phase, not mentioning other phases. Accordingly, a standardization of CGU's analysis activities regarding the preparation of audit reports was not detected in such agreements between the Ministry of Sports and other entities.

Specifically for this research, the focus was the inconsistencies related in the audit reports since they clarify facts linked to possible corruption practice in public management. Thus, in the sample of 40 reports, in 17 were found inconsistencies, according to the following table. 


\begin{tabular}{|l|r|r|r|}
\hline Typeofhiring & Consistent quantity & Inconsistent quantity & Total quantity \\
\hline Price competition (PC) & 01 & 02 & 03 \\
\hline Invitation (IV) & 00 & 03 & 03 \\
\hline Exemptions from bidding (EX) & 00 & 07 & 07 \\
\hline Unenforceabilities (UN) & 00 & 02 & 02 \\
\hline Differentiated hiring system (DH) & 00 & 02 & 02 \\
\hline Princing (PR) & 02 & 01 & 03 \\
\hline Total & 03 & 17 & 20 \\
\hline
\end{tabular}

Table 3. Reports by consistent and inconsistent quantity according to the type of hiring

CGU attributed analyzes indicating that 12 (1 Price Competition, 2 Invitations, 6 Exemptions from Bidding, 1 Pricing, and 2 Unenforceabilities) did not carry out relevant disclosure in media, such as required under Act 8,666/93 (Brasil, 1993).

From the 7 processes carried out as Exemption from Bidding, in 5 there was no justified motivation to characterize the non-bidding, according to the precepts established in Act 8,666/93 (Brasil, 1993).

Jain (2001) points out that there is a relationship between disregard for legislation and the lack of effectiveness of a country's legal system and also that this may lead to increased corruption by its political elite. Thus, CGU notes demonstrating aspects regarding Act 8,666/93 (Brasil, 1993) characterize an attempt by the elite to reduce them, the legal system manipulation in the allocation of resources or even possible key positions within the legal system itself, which causes corruption to spread further.

Regarding the opening to the participation of other companies in such a huge event, that is, companies also with technical capacity to provide a service or sale of goods highlighted in the Term of Reference (document that discriminates the object of hiring), thus contributing to the competition, there are indications that 6 Exemptions from Bidding, 1 Unenforceabilities and 2 Invitations were restrictive, without considering more participants in the hiring process.

It should be noted that in some types of hiring, such as the Invitation, companies are chosen and invited due to the specific products or services that they provide. As for the Unenforceability, the same is attributed when the good or service to be acquired is something very restricted, as specified in Act 8,666/93 (Brasil, 1993). The main remark regarding the restriction and use of waysin disagreement with the hiring Act is in 6 Exemptions from Bidding, indicating that this attitude of the manager was conducted in order to benefit some to the detriment of others.

With regard to UN precepts, the non-opening of hiring for the largest number of participants indicates a restriction of competition, thus impacting on a risk to the possible practice of corruption (Matheson et al., 2018; Rose-Ackerman, 1997; UNODC, 2013). In addition, in 3 Exemptions from Bidding, there were shortcomings in the preparation of budgets for the verification of market values. In one of the Price competitions and in one of the Differentiated Hiring System there have been tacit failures related to the preparation of the previous budget, which serves as the basis for the hiring. For the UN (UNODC, 2013), values out of the standards hired in the market are also indications of the practice of corruption. In this sense, to avoid it, the observation is that electronic processes should be explored in public hiring.

In one of the Pricings, the Bidding Announcement had only one page where all the requirements for the hiring were not considered, such as the bidding mode (pricing), the type of bidding (lower price and better payment conditions) and the place, day and time of the envelopes opening with the proposals. Indicating conditions in bidding procedures mitigates opportunities for corruption (UNODC, 2013).

In one of the exemptions there was a failure to detail the products, so that the measurement of payments could be carried out according to the delivery stages. An observation about another exemption is in the lack of clear definition of the object, which may lead to payments that are not indicated in the contract. There is a concern to make financial expenditures in order to accurately contemplate what is expected as products in such hiring. 
Also, regarding such exemptions related to the bidding procedure, CGU detected that in one of the exemptions the bidder did not observe the possibility that equivalent activities would be inserted in different agreements and hired for the same period. As a result, there was duplication of text translation and public relations services. Therefore, there is waste of resources due to double hiring.

In the same way as contracting in duplicate, the Ministry of Sports incorporated to a Differentiated Hiring System the implementation of an air conditioning system, and this object was the responsibility of a publicprivate partnership between the City Hall of Rio de Janeiro and the Rio Mais Consortium.

In addition, in two exemptions, the peculiarities related to the hiring of the information technology system according to IN SLTI no. 04/2010 (Brasil, 2010) regarding the provision of the "Collaborative System of Projects" were also not observed.

In the Price competition, it was also observed that participating companies did not have expertise for the construction of an Olympic swimming pool. Such companies should be excluded from the process and not have participated in the event.

With regard to the two Invitation processes, it was found that the bidding was conducted in order to benefit the chosen company. The facts are that there was no proof of invitation to potential companies that could participate in the bidding process. In addition, even though having a disqualification of companies with conflicts of interest in the bidding procedures, it was found that the winning companies were also with the same issue, characterizing, once again, favoritism in hiring.

UN argues that in these types of hiring there is a risk of corruption due to restrictions placed on participation that is pre-established. The way to minimize such practice may be through credential requirements of the participants, which did not occur in a timely manner in the Invitation modalities highlighted above. Moreover, favoritism is a high risk for corruption (Olmos et al., 2020; UNODC, 2013).

In one of the Invitations, CGU detected that the amount established in the acquisition of equipment was superior to that indicated in the previous budgets, indicating a loss of public resources. The Table 4 summarizes the main findings regarding the inconsistencies by type of bidding according to Act 8,666/93 (Brasil, 1993).

\begin{tabular}{|c|c|c|c|c|c|c|}
\hline \multirow{2}{*}{ Inconsistencies (Act 8,666/93) } & \multicolumn{6}{|c|}{ Quantity by type of hiring } \\
\hline & PC & IV & EX & IN & $\mathrm{DH}$ & PR \\
\hline Publication & & 01 & 06 & 02 & & \\
\hline No justification to use the type of hiring chosen & & & 05 & & & \\
\hline Budget failures & 01 & 03 & & & 01 & \\
\hline Failure to prepare the bidding announcement & & & & & & 01 \\
\hline Product detail failure & & & 02 & & & \\
\hline Double hiring & & & 01 & & 01 & \\
\hline $\begin{array}{l}\text { Participation of companies without technical expertise to perform } \\
\text { the contract }\end{array}$ & 01 & & & & & \\
\hline Bid to benefit winning company & 02 & & & & & \\
\hline No specific hiring observation & & & 02 & & & \\
\hline Amount contracted in disagreement with budgeted & 01 & & & & & \\
\hline
\end{tabular}

PC = Price competition; IV = Invitation; EX = Exemption from bidding; UN = Unenforceabilities; $\mathrm{DH}=$ Differentiated hiring system; and PR = Pricing

Table 4. Inconsistencies by type of bidding according to Act 8,666/93

Continuing the analysis on the 17 reports mentioned above, some highlights were made on the performance of the contract. The first highlight is in payment failures. In one of the Price competition cases, the contractor made payments in disagreement with the law and that established in contract. In an Exemption from bidding there were expenditures that were not foreseen in the work plan. For that which was foreseen, there was another contract causing duplication of payments and, as well as hiring of accounting service without due justification. 
In another exemption, different from the previous one, the private company received a higher amount than stipulated in the contract.

In one of the Pricings, the company agreed to make payments before the delivery of the equipment that were object of the contract. In another contract through Differentiated Hiring System, there was an advanced payment of services not yet executed.

In addition to these, after hiring for Exemption from bidding between the Ministry of Sports and other entities, there were some irregularities regarding the conduct of both the contractor and the private company.

In three Exemptions from bidding the execution of services by personnel not belonging to the hired entity was verified, which makes the option of Exemption as established in Act 8,666/93 (Brasil, 1993) impossible. This indicates that the hired company did not have personnel technically qualified to execute the agreed object, a servicer, having to perform sub-hiring.

In addition, in another exemption from bidding, different from the ones mentioned in the previous paragraph, the Secretariat belonging to the Ministry of Sports authorized the execution of clipping activities without it being in the scope of the contract. Also, the Ministry authorized the execution of services without the formalization of the contract. This finding was based on invoices analyses that were certified by the products delivery in conformity, with a date prior to the signing of such agreement.

Similar to the previous one, there was another Exemption from Bidding in which there was authorization to carry out clipping activities, not foreseen in the scope of the contract. Sub-hiring was also carried out, making it impossible to make the exception, since it should have technically qualified people in its human resources.

In one of the Invitations, through an agreement, it was difficult to perform the audit of the assets acquired, since they had not yet been identified with records of equity.

It was observed that in a Price competition and Exemption from bidding, using Terms of Commitment, there was a change in the basic project for the construction of goods without technical team's endorsement, breaking the bidding announcement forecasts of such hired objects.

Finally, one of the Exemptions signed by contract incurred in disagreement as to the payment of taxes by the contractor, as well as in inconsistencies in the calculation of the amounts to be paid to Executive Coordinators and Project Consultants. That is, the values were in disagreement with the original one in the National Register of Social Information, which should be the basis to receive the payment of such activities. Table 5 presents a summary of the main findings in the later executions.

\begin{tabular}{|l|r|r|r|r|r|r|}
\hline \multirow{2}{*}{ Inconsistencies in the execution } & \multicolumn{5}{|c|}{ Quantity by type of hiring } \\
\cline { 2 - 6 } & PC & IV & EX & UN & DH & PR \\
\hline Undue payment & & 02 & 02 & & 01 & 01 \\
\hline $\begin{array}{l}\text { The contractor did not have in its human resources } \\
\text { technically trained personnel }\end{array}$ & & & 03 & & & \\
\hline Authorization of execution of service in discordance & & & 02 & & & \\
\hline Failure to identify assets in a timely way & 01 & & & & & \\
\hline Change in initial project without authorization & 01 & & 01 & & & \\
\hline Lack of payment of taxes & & & 01 & & & \\
\hline Undue definition of service payment & & & 01 & & & \\
\hline
\end{tabular}

PC = Price competition; IV = Invitation; EX = Exemption from bidding; UN = Unenforceabilities;

$\mathrm{DH}=$ Differentiated hiring system; andPR $=$ Pricing

Table 5. Executions after delivery of the products or services

It is important to emphasize that on the inspection of contracts and agreements signed between the Ministry of Sports and private entities, it was verified that there were failures in the inspection of such partnerships. The evidence is that, in five contracts and four agreements, there was a failure in the management of the activities related to the inspection, resulting in timeliness in the information on the contractual execution. 
Regarding the use of information published by the press, Cohen, Ding, Lesage and Stolowy (2010) considered a form of ex-post facto validation of cases of fraud in their article that verified facts of illicit in the American private area. Miller (2006) calls the press as the society's monitoring in the identification of improprieties or illicit, processing information of public and restricted nature combined in an analysis that points out potential problems. Based on these concepts the analysis of media was delimited as follows:

\begin{tabular}{|r|r|r|}
\hline Year & Found news & Analysed news \\
\hline 2009 & 1 & 1 \\
\hline 2011 & 1 & 1 \\
\hline 2013 & 1 & 1 \\
\hline 2014 & 3 & 3 \\
\hline 2015 & 12 & 9 \\
\hline 2016 & 38 & 34 \\
\hline Total & 56 & 49 \\
\hline
\end{tabular}

Table 6. Media analysis of the period

A protocol for the collection of media information was set out in The Guardian newspaper. They were collected through Google, with the determination of parameters in "advanced search". Another need of the research was the seek for words like "corruption", "deviations" and others that were related to possible illicit or evidences of such questions. News that does not have any relation with the proposed content, merely sporting matters or other facts, have not been previously filtered for the analysis.

2016, which was exactly when the Games occurred, had the largest number of related news. However, only 38 were selected by a criterion of exhaustion of the subject since the content analyzed already presented similarity as to the news pressed. We have intentionally decided to use the first seven pages of content presented by the browser.

The year of the Olympic Games in Rio totaled 38 selected news items and 34 analyzed, of which 4 were later discarded because they were not directly related to the theme, since they mentioned police violence, Rio local elections, death of a leader and a compilation of other news. The same thing was observed in 2015 , with 12 news items and 9 analyzed.

Following the precepts of content analysis, it was defined within the software Nvivo categories for events analysis pointed by the press. The categories observed by the researchers were defined as follows:

\begin{tabular}{|c|c|c|c|c|c|c|c|}
\hline Categories & 2009 & 2011 & 2013 & 2014 & 2015 & 2016 & Total \\
\hline Bribe/Construction/Bid & & & 1 & & & 6 & 7 \\
\hline Electoralcorruption & 1 & & & & 1 & & 2 \\
\hline Corruption in the Olympic Committee & & & & 1 & 1 & 6 & 8 \\
\hline Politiciansandpeople & & 1 & & & 5 & 20 & 26 \\
\hline Budgetaryproblems & & & & 1 & & 6 & 7 \\
\hline Protests & & & & 2 & 3 & 3 & 8 \\
\hline Legacy & & & & 1 & 3 & 8 & 12 \\
\hline Totals & 1 & 1 & 1 & 5 & 13 & 49 & 70 \\
\hline
\end{tabular}

Table 7. Categories of events observed in the research

The year 2009 presented only one occurrence related to the election of Rio de Janeiro as host of the Olympic Games and possible indiscriminated use of resources in corruption and as a form of electoral roll, presenting a possible opportunistic action of the political agents involved. The year 2011 is presented, as well as 2009, with a relatively low volume of related news. However, the resignation of the Minister of Sports Orlando Silva for possible involvement in corruption once again points to the opportunistic action of agents and evidence of corruption. 
The year 2013 is marked by scandals involving construction companies and problems with bidding for the construction of World Cup facilities, which would also be used in the Olympic Games, pointing to the misuse of public resources and favoring large companies.

In some news, more than one category of possible illicit or press events were verified, such as in the case of 2014 in which issues were related to the corruption of the International Olympic Committee, budget problems in Rio de Janeiro, protests and a tendency of identification of eventual legacy of the games for the city.

The year 2016, the largest in volume of news for the games, also stands out for them involving research on public policies and people. In this case, the investigation of former president Lula, the impeachment of President Dilma and the arrest of former governor of Rio de Janeiro Sérgio Cabral. All of them were involved in some act of corruption and related directly or indirectly to the issue of the games, constructors or other Brazilian political events.

Corruption can be understood in different ways and acts in society corrupting institutions or systems as a whole. Evidence of corruption and illicit acts has always been associated with society, and specifically with the Olympic Games, and with an event occurring in Rio de Janeiro in 2016 was no different (Maennig, 2005; Mason et al., 2006; Matheson et al., 2018).

The Public Choice Theory points to the preferences of the public agents as representatives of the collective interest, and as they are observed under an individualistic gaze, there are occasional opportunistic issues in their actions (Gwartney \& Wagner, 1988; Mbaku, 2008). To emphasize this perspective, the Public Choice Theory explored by Buchanan and Tullock (1962) was used.

In this research, we sought to understand the choices made by politicians (agents) to maximize the collective well-being (principal) and the possible restrictions to combat the opportunism of these managers to limit possible signs of corruption.

The analysis focused on the definition of corruption proposed in the literature (Banerjee, 2019; Pfleegor et al., 2019), in the article 9 of the United Nations Office of Drugs and Crime Manual (UNODC, 2013), as well as in the laws in force in Brazil to base the research findings.

Checking the findings presented in CGU's audit reports for 2014, 2015 and 2016, it was possible to observe problems arising from the relationship between agent and principal as exposed by Jensen and Meckling (1976) and that from an opportunistic perspective can explain possible acts of management and political decisions made. Some of the analyzed points presented compliances, but the inconsistencies were the focus of the research analysis. Consequently, 17 reports presented inconsistencies related mainly to the bidding procedure, according to Matheson et al. (2018), one of the latent hypotheses of evidence of corruption and possible deviations in the use of public resources and choices of political agents (Buchanan \& Tullock, 1962).

Notes related to non-opening of hiring procedures, exemptions from biddings, use of an invitation letter not in a timely manner, lack of competition between companies in the market, sub-hiring of companies by contractors, disqualifying the bidding process, favoritism and other irregularities point to possible practices of corruption characterized by the UN (UNODC, 2013) in its document that aims to mitigate the main harms of this type of behavior.

As pointed out by Jain (2001), weaknesses in controls and political systems denote possibilities of increasing corruption and allow the manipulation of public resources, contributing to corruption spreading even more.

Regarding the legacy, there was a tendency to increase the news. However, they point to the problems faced by the city of Rio de Janeiro. Among other subjects, they also characterized deviations, corruption, police violence, lack of planning among other problems. 


\section{Conclusions}

This paper aimed to investigate the role of CGU audit in the prevention and detection of evidence of corruption in the Olympic Games in Rio de Janeiro in 2016.

CGU inspection and audit reports were investigated as well as media content from The Guardian and Le Monde newspapers. The press also stood out in this process by reporting the possible purchase of the Olympic Games in Rio de Janeiro among other evidences of corruption.

The results evidenced transfers from the Ministry of Sports to other hired, agreed or under partnership terms entities, since this ministry was responsible for carrying out various actions for the 2016 Olympic Games. A total of 41 reports were analyzed, being1 excluded because it was not related to the main subjects. From these, 20 documents were related to the acquisition of services, such as preparation of athletes and advisory services, and the rest were related to goods and services, among others.

The analyzed points presented some compliances, but the inconsistencies were the focus of the research analysis. In the 17 analyzed reports, there were inconsistencies, mainly related to the bidding process, that established one of the latent hypotheses of corruption and possible deviations in the use of public resources, considering the choices of political agents.

Notes were made related to non-opening of hiring processes, exemptions of bidding, use of invitation letter in a not timely manner, lack of competition between companies in the market, sub-hiring of companies by contractors, which disqualifies the bidding process, with latent evidence of favoritism. Other irregularities point to possible corrupt practices characterized.

The weaknesses identified in the controls and in the political system denote possibilities of increasing corruption and allow the manipulation of public resources, contributing to systemic corruption in Brazil.

In the press analysis, the use of information published in The Guardian and Le Monde shows acts involving bribes, illegalities involving construction companies and bidding processes. The news on the investigation of politicians such as former sports minister Orlando da Silva, former president Lula, impeached president Dilma, former governor of Rio de Janeiro Sérgio Cabral, arrested at the end of 2016, the president of the Brazilian Olympic Committee Carlos Arthur Nuzman, arrested in the middle of 2017 and other members of the National and International Olympic Committee are highlights. However, after some short time in jail, most of them are being released after legal maneuvers, which denotes the good payment for the corruption.

These findings point to the contribution of institutionalized democracy in Brazil in the pursuit of transparency and accountability, the increasing of its control systems and also the prominence of the free press, which evidenced the importance of the Accounting Offices, Brazilian Government Agency for Law Enforcement and Comptroller General of Brazil, in mitigating the opportunism of public agents.

The limitations of this research are based on the scope of the investigation carried out that sought to analyze the available content by the official control board that conducted the audit and the newspapers The Guardian and Le Monde. Although this approach developed through the content analysis did not affect the survey orthe findings proposed in this research, it presented in a systematic way the results.

A suggestion for further research would be to conduct event studies relating notorious facts by crossing evidence of corruption and other illicit elements, with the outcomes of ongoing investigations in the Brazilian justice and the repercussion in the Brazilian and world wide societies.

\section{Declaration of Conflicting Interests}

The authors declared no potential conflicts of interest with respect to the research, authorship, and/or publication of this article. 


\section{Funding}

This study was financed in part by the Coordenação de Aperfeiçoamento de Pessoal de Nível Superior - Brasil (CAPES) - Finance Code 001.

\section{References}

Abdul, S.L.M.M.S., Yusoff, H., \& Mohamed, N. (2019). Factors that might lead to corruption: A case study on Malaysian government agency. International Journal of Financial Research, 10(3), 216. https://doi.org/10.5430/ijfr.v10n3p216

Adanali, Y.K. (2017). Rational choice theory: Its merits and limits in explaining and predicting cultural behavior. Erasmus Journal for Philosophy and Economics, 10(1), 137-141. https://doi.org/10.23941/ejpe.v1011.272

Anderson, T.L., \& Hill, P. (1986). Constraining the transfer society: Constitutional and moral dimensions. Cato Journal, 6(1), 317-345.

Andreff, W. (2019). An economic roadmap to the dark side of sport: Corruption in sport. Switzerland: Springer Nature. https://doi.org/10.1007/978-3-030-28479-4

Andvig, J., Fjeldstad, O.-H., Amundsen, I., Sissener, T., \& Søreide, T. (2001). Corruption: A review of contemporary research. Norway: Chr. Michelsen Institute.

Banerjee, S. (2019). Foreign direct investments: Examining the roles of democracy, corruption and judicial systems across countries. Journal of Applied Business and Economics, 21(6). https://doi.org/10.33423/jabe.v21i6.2398

Barbosa da Silva, A., Godoi, C.K., \& Bandeira-de-Mello, R. (2010). Pesquisa qualitativa em estudos organizacionais: Paradigmas, estratégias e métodos (2a edição). São Paulo: Saraiva.

Bardin, L. (2009). Análise de conteúdo. Lisboa: Edições 70.

Brasil. Lei 8.666 (1993). Regulamenta o art. 37, inciso XXI, da Constituição Federal, institui normas para licitações e contratos da Administração Pública e dá outras providências.

Brasil. Instrução Normativa 04 de 12 de novembro de 2010 (2010). Dispõe sobre o processo de contratação de Soluções de Tecnologia da Informação pelos órgãos integrantes do Sistema de Administração dos Recursos de Informação e Informática (SISP) do Poder Executivo Federal.

Brasil. Lei 12.462 (2011). Institui o Regime Diferenciado de Contratações Públicas_RDC; altera a Lei no 10.683, de 28 de maio de 2003, que dispõe sobre a organização da Presidência da República e dos Ministérios, a legislação da Agência Nacional de Aviação Civil (Anac) e a legislação da Empresa Brasileira de Infraestrutura Aeroportuária (Infraero); cria a Secretaria de Aviação Civil, cargos de Ministro de Estado, cargos em comissão e cargos de Controlador de Tráfego Aéreo; autoriza a contratação de controladores de tráfego aéreo temporários.

Brasil. (2017a). Ministério do Esporte.

Brasil. (2017b). Transparência e Controladoria-Geral da União.

Brittain, I., Bocarro, J., Byers, T., \& Swart, K. (2017). Legacies and mega events: Fact or fairy tales? (1st ed.). London: Routledge. https://doi.org/10.4324/9781315558981

Buchanan, J., \& Tullock, G. (1962). The calculus of consent: Logical foundations of constitutional democracy Ann Harbor: L. Fund, Ed. https://doi.org/10.3998/mpub.7687

Clarke, J., \& Ojo, J.S. (2017). Sport policy in Cameroon. International Journal of Sport Policy and Politics, 9(1), 189200. https://doi.org/10.1080/19406940.2015.1102757

Cohen, J., Ding, Y., Lesage, C., \& Stolowy, H. (2010). Corporate fraud and managers' behavior: Evidence from the press. Journal of Business Ethics, 95(SUPPL. 2), 271-315. https://doi.org/10.1007/s10551-011-0857-2

da Costa, L.P. (2008). Legados de megaeventos esportivos. Brasília: Ministério do Esporte.

Darós, L.L., \& Pereira, A. de S. (2009). Análise das normas brasileiras de contabilidade aplicadas ao setor público (NBCASP): Mudanças e desafios para a contabilidade pública. Congresso USP de Iniciação. 
Decker, W. (2019). A prearranged affair. Towards papyrus oxyrhynchus 5209. Diagoras: International Academic Journal on Olympic Studies, 3, 32-44.

Dichter, H.L. (2016). Corruption in the 1960s?: Rethinking the Origins of Unethical Olympic Bidding Tactics. International Journal of the History of Sport, 33(6-7), 666-682. https://doi.org/10.1080/09523367.2016.1195374

Gibbs, G. (2009). Análise de dados qualitativos. Retrieved from: http://site.ebrary.com/id/10765292

Gwartney, J.D., \& Wagner, R.E. (1988). Public Choice and the conduct of representative governement. In Political Economy and Public Policy (pp. 3-28). London: JAI Press.

Iossa, E., \& Martimort, D. (2016). Corruption in PPPs, incentives and contract incompleteness. International Journal of Industrial Organization, 44, 85-100. https://doi.org/10.1016/j.ijindorg.2015.10.007

Jain, A.K. (2001). Corruption: A review. Journal of Economic Surveys, 15(1), 71-121. https://doi.org/10.1111/14676419.00133

Jensen, M.C., \& Meckling, W.H. (1976). Theory of the firm: Managerial behavior, agency costs and ownership structure. Journal of Financial Economics, 3(4), 305-360. https://doi.org/10.1016/0304-405X(76)90026-X

Kelman, S. (1987). "Public choice" and public spirit. The Public Spirit, 70, 80-94.

Lima, E.C.P. (2016). A Democracia e seus problemas: Breves notas à luz da teoria da escolha pública. Revista Controle - Doutrina e Artigos, 14(2), 13-30. https://doi.org/10.32586/rcda.v14i2.343

Liu, C., Moldogaziev, T.T., \& Mikesell, J.L. (2017). Corruption and state and local government debt expansion. Public Administration Review, 77(5), 681-690. https://doi.org/10.1111/puar.12711

Maennig, W. (2005). Corruption in international sports and sport management: Forms, tendencies, extent and countermeasures. European Sport Management Quarterly, 5(2), 187-225.

https://doi.org/10.1080/16184740500188821

Mason, D.S., Thibault, L., \& Misener, L. (2006). An Agency Theory perspective on corruption in sport: The case of the International Olympic Committee. Journal of Sport Management, 20(1), 52-73.

https://doi.org/10.1123/jsm.20.1.52

Matheson, V.A., Schwab, D., \& Koval, P. (2018). Corruption in the bidding, construction and organisation of mega-events: An analysis of the Olympics and World Cup. In M. Breuer \& D. Forrest (Eds.), The Palgrave Handbook on the Economics of Manipulation in Sport (pp. 257-278). https://doi.org/10.1007/978-3-319-77389-6_14

Mbaku, J.M. (2008). Corruption Cleanups in Africa: Lessons from Public Choice Theory. Journal of Asian and African Studies, 43(4), 427-456. https://doi.org/10.1177/0021909608091975

Miller, G.S. (2006). The press as a watchdog for accounting fraud. Journal of Accounting Research, 44(5), 1001-1033. https://doi.org/10.1111/j.1475-679X.2006.00224.x

Monteduro, F., Hinna, A., \& Moi, S. (2016). Governance and Corruption in the Public Sector: An Extended Literature Review. Governance and Performance in Public and Non-Profit Organizations (Studies in Public and NonProfit Governance, Volume 5), 31-51. https://doi.org/10.1108/S2051-663020160000005002

Olmos, L., Bellido, H., \& Román-Aso, J.A. (2020). The effects of mega-events on perceived corruption. European Journal of Political Economy, 61, 101826. https://doi.org/10.1016/j.ejpoleco.2019.101826

Pfleegor, A.G., Soebbing, B.P., \& Seifried, C. (2019). Corruption, rule-breaking, and sanctions: The case of the NCAA. Journal of Global Sport Management, 4(1), 38-60. https://doi.org/10.1080/24704067.2018.1493355

Rose-Ackerman, S. (1997). Democracy and 'grand' corruption. International Social Science Journal, 48(3), 9-12. https://doi.org/10.1007/s12117-997-1060-9

Seter, H., Theisen, O.M., \& Schilling, J. (2018). All about water and land? Resource-related conflicts in East and West Africa revisited. GeoJournal, 83(1), 169-187. https://doi.org/10.1007/s10708-016-9762-7 
Shleifer, A., \& Vishny, R.W. (1993). Corruption. The Quartely Journal of Economics, 108, 599-617. https://doi.org/10.2307/2118402

UNODC (2013). Guidebook on anti-corruption in public procurement and the management of public finances.

Yavuz, Y. (2016). The relationship between fan identification and moral disengagement of physical education and sports students. Educational Research and Reviews, 11(7), 402-410. https://doi.org/10.5897/ERR2015.2541

Intangible Capital, 2020 (www.intangiblecapital.org)

\section{(c) (i) $\$$}

Article's contents are provided on an Attribution-Non Commercial 4.0 Creative commons International License. Readers are allowed to copy, distribute and communicate article's contents, provided the author's and Intangible Capital's names are included. It must not be used for commercial purposes. To see the complete license contents, please visit https://creativecommons.org/licenses/by-nc/4.0/. 